\title{
The Untoward Effects of Cigarettes and Drugs: Some Reflections on Enterprise Liability
}

\author{
Fleming James*
}

The tendency of CIGARETtes to cause cancer in some people has 1 become increasingly recognized. ${ }^{1}$ Drugs, many of them useful and valuable, sometimes have serious, even fatal, side effects for a few people. $^{2}$ The possible liability of the maker of such a product to its occasional hapless victim under currently developing tort doctrines presents interesting questions concerning what Professor Elrenzweig has felicitously called enterprise liability, ${ }^{3}$ and its proper limits.

The current trend in products liability cases is toward imposing strict hability on the maker for the injurious effects of his product upon a consumer or user when it is put to a foreseeable use. ${ }^{4}$ But this liability, like that for negligence, is conditioned upon the existence of an unreasonably dangerous quality of the product whicl causes injury. This newer liability is strict, but not absolute. It relieves the plaintiff from the need

*B.A., 1925, LL.B., 1928, Yale University; Professor of Law, Yale University.

${ }^{1}$ See, e.g., Green v. American Tobacco Co., 304 F.2d 70 (5th Cir. 1962), 154 So, 2d 169 (Fla. 1963) (answering question certified by U.S. Court of Appeals), 325 F.2d 673 (5th Cir. 1963), cert. denied, 377 U.S. 943 (1964); Pritchard v. Liggett \& Myers Tobacco Co., 295 F.2d 292 (3d Cir. 1961), 350 F.2d 479 (3d Cir. 1965); Ross v. Philip Morris \& Co., 328 F.2d 3, 11 n.8 (8th Cir. 1964); Lartigue v. R. J. Reynolds Tobacco Co., 317 F.2d 19 (5th Cir. 1963); Rossi, The Cigarette-Cancer Problem: Plaintif's Choice of Theories Explored, 34 So. CAL. L. Rev. 399 (1961); Comment, Cigarettes and Vaccine: Unforeseeable Risks in Manufacturers Liability Under Implied Warranty, 63 Coros. L. Rev. 515 (1963).

See also Restatement (Second), Torts § 402A, comment i (1965); Traynor, The Ways and Meanings of Defective Products and Strict Liability, 32 TENN. L. REv. 363, 371-73 (1965); P. Keeton, Products Liability-Liability Without Fault and the Requirement of a Defect, 41 Texas I. Rev. 855, 868-73 (1963).

2 See, e.g., Love v. Wolf, 226 Cal. App. 2d 378, 38 Cal. Rptr. 183 (1964); Magee v. Wyeth Labs., Inc., 214 Cal. App. 2d 340, 29 Cal. Rptr. 322 (1963); Cochran v. Brooke, 409 P.2d 904 (Ore. 1966); Witmore, Allergies and Other Reactions Due to Drugs and Cosmetics, 19 Sw. L.J. 76 (1965); Comment, 63 Corom. L. Rev. 515 (1963); Restateament (SECOND), ToRTs § 402A, comment k (unavoidably unsafe products) (1965).

3 Eereanzwetg, Negligence Without FaUtr (1951), which bears the subtitle "Trends Toward An Enterprise Liability for Insurable Loss." Id. at title page. See also Ehrenzweig, Guest Statutes in the Conflict of Laws, 69 YALE L.J. 595 (1960); Ehrenzweig, Products Liability in the Conflict of Laws, id. at 794 ; Ehrenzweig, Vicarious Liability in the Conflict of Laws, id. at 978. Each article bears the subtitle: "Towards a Theory of Enterprise Liability Under 'Foreseeable and Insurable Lazes.'”

4 See, e.g., Wade, Strict Tort Liability of Manufacturers, 19 Sw. L.J. 5 (1965); Prosser, Toris 678 (3d ed. 1964); Restatement (SeCOND), Torts \& 402A (1965). 
to sliow that the unreasonably dangerous quality or condition was either caused by the maker's negligence or could have been remedied by his due care; but the quality or condition must still be shown. ${ }^{5}$ And this fits in very well with Professor Ehrenzweig's notion of enterprise liability: without fault, but limited to those losses whicl are "typically" caused by the enterprise in question. ${ }^{6}$ There are, however, and no doubt should be, other limitations upon liability in addition to the one embodied in the concept of typicality. We shall explore these questions concerning the nature of enterprise liability and its proper limits with respect to known dangers and also dangers not known or knowable when the injury occurred.

${ }^{5}$ See sources cited note 4 supra; 2 Harper \& JAMres, TORTS $\$ 28.22$ (1956).

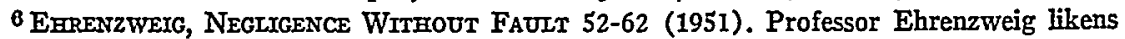
the typicality test he urges for enterprise liability to the contractual contemplation test in Hadley v. Baxendale, 9 Ex. 341, 156 Eng. Rep. 145 (1854), which, as he says, "is distinct from the traditional foreseeability test of the negligence rule . . ." Id. at 54 . Under the typicality test, "anticipation of harm at the time of the start of the activity rather than the time of the injurious conduct determines the scope of liability. It is this determination which reveals the rationale of the non-fault liabilities discussed: these liabilities are the price which must be paid to society for the permission of a hazardous activity." Id. at 54 (italics in original).

The significance of considering foresight from the time of entering into the activity is that this is the critical time for the entrepreneur to be able to calculate the costs of his undertaking so as to decide whether to enter it and, if he does, to plan provision for these costs by insurance or otherwise. See sources cited supra note $3 ; 2$ HARPER \& JAMres, TORTS 1376 (1956).

Implicit in this line of reasoning may be another which suggests a similar result. The optimum allocation of resources in a free enterprise system requires each enterprise to pay its own accident costs. Calabresi, Some Thoughts on Risk Distribution and the Law of Torts, 70 YALE L.J. 499 (1961); Calabresi, The Decision for Accidents: An Approach to Nonfault Allocation of Costs, 78 HARv. L. Rev. 713 (1965). See also James, An Evaluation of the Fault Concept, 32 TrNov. L. Rev. 394, 400 (1965). This view obviously raises the question of what costs of making and distributing a product are properly attributable to the enterprise. If the economist can indeed contribute hittle or nothing useful to the solution of this question (see Broms \& Kalven, Public Law Perspectrves on a Private Law Problexs 60, 61 (1965); Morris, Enterprise Liability and the Actuarial Process-The Insignificance of Foresight, 70 YALE L.J. 554, 583-93 (1961)), surely little quarrel can be had with a political or judicial judgment which attributes to the maker's enterprise the cost of unreasonable dangers which inhere in his product. Such a judgment would probably tend ultimately to distribute such costs among all consumers of the product. But cf., Morris, supra at 584-87. Since victims of the product's danger are to be found within the consumer class, Blum and Kalven argue that "whether, liability is placed on the industry or the loss is left with the consumers, the economy will be equally responsive to consumer voting and consumers as a class will cast the same vote. The law's choice of liability rules thus would seem to have no impact on the allocation of resources in the society." BLOM \& KaIveN, op. cit. supra at 59. But where "the loss is left with the consumers" a very few individuals among them bear the whole loss, each of his own injury. And it seems doubtful indeed that users as a class, the vast majority of whom are completely unaffected by these losses, will be as likely to evaluate the risk (or cost) as accurately as if each were charged his aliquot share. 
WHEN KNOWN DANGERS ARE "UNREASONABLE"

The dangers which inhere in some products are well and widely known. There can be no serious question whether they are, in Ehrenzweig's sense, typical of the product, or rather of the enterprise of making and distributing it. Yet the law may deny liability for injuries caused by them for other reasons.

The question whether such dangers are unreasonable ones is, at its extremities, tinged with political considerations that may transcend the judicial function. Whiskey, for instance, undoubtedly does serious harm to some people, partly because of its tendency to induce excessive use by some, and partly because of the physical and other harm that may come from excessive use. Like the tendency of strawberries to cause hives to occasional sensitive users, these injurious tendencies of whiskey are widely known. In both cases a warning would do little or nothing towards prevention of the evil. But the cases are unlike in important respects. The seriousness of the harm threatened is very different in the two, and, because of the habit-forming tendencies of whiskey for some people, so is the effectiveness of self-protective care that may be expected of users.

A former generation of Americans found that these evils outweighed any advantages to be derived from using whiskey as a beverage, and made a political decision forbidding its manufacture and sale for such purposes. But the noble experiment of prohibition did not work, and the constitutional amendment and legislation embodying it were repealed. This again represented a political judgment that the benefits to be derived from drinking whiskey as a beverage, and perhaps from protecting the individual's freedoin of choice about such matters, taken together with the collateral evils of prohibition, outweighed the evils that undoubtedly come to some people from the use of whiskey.

In the light of this political judgment, it would seem arbitrary for courts to hold a whiskey distiller liable for the foreseeable injurious effects to some people of whiskey which has standard ingredients and qualities. ${ }^{7}$ The political judgment would seem to foreclose a judicial

7 This line of reasoning was suggested to the author by the provocative and often quoted statement of Judge Goodrich in his concurring opinion in Pritchard v. Liggett \& Myers Tobacco Co., 295 F.2d 292, 302 (3d Cir. 1961) ("If a man buys whiskey and drinks too much of it and gets some liver trouble as a result $I$ do not think the manufacturer is liable unless (1) the manufacturer tells the customer the whiskey will not lurt him or (2) the whiskey is adulterated whiskey-made with methyl alcohol, for instance."), and by Justice Traynor's thoughtful article, The Ways and Meanings of Defective Products and Strict Liability, 32 TenN. L. Rev. 363 (1965). See also Restatement (SECOND), TORTS \& 402A, comment i (1963) ("Good whiskey is not unreasonably dangerous merely because it will make some people drunk, and is especially dangerous to alcoholics; but bad whiskey, containing a dangerous amount of fusel oil, is unreasonably dangerous."). 
holding that the recognized dangers of whiskey render it unreasonably dangerous. Nor is it easy to think of an effective warning or feasible precaution on the distiller's part. Precautions of this kind are again largely matters to be adopted by the political process and enforced against (or by) distributors rather than manufacturers of whiskey.

To a certain extent, though less dramatically and more equivocally, the inatter of cigarettes and beneficial but dangerous drugs stands on the same footing. It is within the legislative power to prohibit the ordinary production of any of these things if the people through their representatives make the political judgnient that their evils outweigh their benefits. Indeed, in the case of new drugs, Congress has forbidden their introduction into interstate commerce unless the Secretary of Health, Education and Welfare has approved an application (with respect to the drug) which must contain full reports of all investigations into its safety, a full list of all the drug's components, its proposed label, and so on. ${ }^{8}$ Moreover, it is beyond question that the legislature has power to regulate the manufacture and sale of cigarettes and drugs. In view of all this it may plausibly be argued that the failure to prohibit represents in a way the exercise of a political judgment that the benefits of the product-if it is produced and distributed in accordance with any legislative or administrative regulations there may be-outweigh its evils and dangers: in other words that the product is not on balance unreasonably dangerous. An even stronger argument would support judicial acceptance of a product's approval by a public official acting as the legislature's delegate.

Four things about this line of reasoning should be noted:

(1) A political judgment may be inferred froin non-action only with respect to those dangers that are so widely known and understood that they may fairly be assumed to have been in the minds of the voters and their representatives. This reasoning, for example, could not rationally justify a ruling that cigarettes were not unreasonably dangerous before their tendency to cause cancer became common knowledge.

(2) The nature of the political process is such that a failure to act legislatively is considerably less likely to represent the choice of the electorate than, for example, the repeal of prohibition did. This fact may mean that there is more roon for judicial judgnient in weighing benefits and evils than there would be where the exercise of judgment through the political process is less equivocal.

(3) An official's approval of a drug or other product under a

8 Federal Food, Drug and Cosmetic Act $\S 505$ (a) and (b), 52 Stat. 1052 (1938) (amended by 76 Stat. 784 (1962)), 21 U.S.C. $\& 355$ (a) and (b) (1964). Section 505(d) sets forth the grounds upon which the Secretary may refuse to approve the application. 52 Stat. 1052 (1938) (amended by 76 Stat. 784 (1962)), 21 U.S.C. $\$ 355$ (d) (1964). 
statute like the federal Food, Drug and Cosmetic Act represents a political judgment only with respect to those dangers disclosed in the maker's application or otherwise brought to the official's attention.'

(4) Even express approval by an official and compliance with all applicable statutory and administrative regulations may not cover the whole field so as to exclude the judicial function. It is familiar general law that such compliance does not always discharge an actor's whole responsibility so far as civil compensation for the injurious consequences of his activities is concerned. ${ }^{10}$ Courts have applied the same reasoning in the present context. Thus the maker's use of the warning required and approved by the proper official has not precluded a judicial finding that the warning is inadequate under some circumstances. ${ }^{11}$

The case of drugs will often be different from that of whiskey and cigarettes in one respect. Warnings and directions for use, which would afford only a mockery of protection against the widely known dangers of drinking and smoking, ${ }^{12}$ would often be effective precautions against at least some of the dangerous side-effects of drugs. ${ }^{13}$ In such a case, putting out the drug without suitable warning or direction might be unreasonably dangerous, ${ }^{14}$ althougl the production of the drug and putting it out with suitable precautions would not be. ${ }^{15}$

Whether the judgment (that a product is, or is not unreasonably dangerous) is made by the political or judicial process, it will involve pretty much the same kind of weighing or balancing of the likelihood of injury, taken together with the seriousness of injury if it should occur, aganist the utility of the product put out without the precaution (if any there is) whicli would effectually avoid or: minimize the risk of injury. ${ }^{10}$

O Cf. Randall v. Goodrich-Gamble Co., 244 Minn. 401, 70 N.W.2d 261 (1955).

102 Harper \& JaMres, TORTS 1014 (1956); Prosser, TORTS 205 (3d ed. 1964).

11 Hubbard-Hall Chem. Co. v. Silverman, 340 F.2d 402 (1st Cir. 1965); Love v. Wolf, 226 Cal. App. 2d 378, 38 Cal. Rptr. 183 (1964).

12 This statement is concerned with warming as a means of imparting knowledge. It may overlook the possible suggestive force of repeated warnings-especially if made dramatic-in counteracting the habit-forming tendencies of such products.

13 There may be situations where, though the danger to a few is recognized, there is no known way to identify those few in advance, and a single use of the drug will do the harm. In such a case it is hard to see what effective precautions can be taken.

14 See Love v. Wolf, 226 Cal. App. 2d 378, 38 Cal. Rptr. 183 (1964), where the words of warning were allegedly counteracted by overpronuotion and statements in advertising calculated to minimize the dangers and put doctors off their guard.

15 Magee v. Wyeth Labs., Inc., 214 Cal. App. 2d 340, 29 Cal. Rptr. 332 (1963); Restatemant (Second), Torts \$ $402 \mathrm{~A}$ comment k (1965). Cf. Cochran v. Brooke, 409 P.2d 904 (Ore. 1966).

It should be noted that when the drug is available ouly on prescription, the warnings and directions should be directed to the medical profession.

16 See P. Keeton, Products Liability-Liability Without Fault and the Requirement of a Defect, 41 Texas I. Rev. 855 (1963); P. Keeton, Products Liability-Cutrent Develop- 
That a danger inherent in a product is well known may also raise questions that concern the plaintiff's conduct. One of these-the defense of assumption of risk or whatever one chooses to call it ${ }^{17}$-lies outside our present inquiry. Another, however, does not. The likelihood that people wlio use the product will in fact take effective self-protective care is certainly a factor to be weiglied in assessing the reasonableness of a product's risk. Knowledge of the danger may make this likelihood greater, ${ }^{18}$ but it will not always do so. Although everyone may know that a product will injuriously affect a few people, there may be no way for an individual to tell wliether lie is one of the unfortunate few until it is too late - until the injurious process has become irreversible. ${ }^{19}$ In such a case, unreasonable danger in putting out the product at all might be found more readily than in a case wliere the injurious tendency can be detected and avoided or headed off before serious harm is done. Even where the latter is impossible, lowever, the utility of the product may make it socially desirable to put it out in spite of the inevitable risk. In such a case the Second Restatement of Torts would not regard the unavoidable danger as an unreasonable one. ${ }^{20}$

II

\section{WHEN UNKNOWN OR UNINNOWABLE DANGERS ARE "UNREASONABLE"}

When we leave the area of widely known dangers, different problems are encountered. In terms of negligence the principal one is scienter. Even if a product is unreasonably dangerous, the maker cannot be found negligent for putting it out or for failing to warn of its danger unless he $\mathrm{knew}$ or, in the exercise of reasonable care, should have known, that danger. ${ }^{21}$

ments, 40 TEXAS L. REv, 193, 210 (1961); Wade, Strict Tort Liability of Manufacturers, 19 SW. L.J. 5, 15 (1965). Cf. 2 HarPer \& JaMRES, LAW of TORTS $§ 16.9$ (1956).

${ }^{17}$ See R. Keeton, Assumption of Products Risks, 19 Sw. L.J. 61 (1965); R. Keeton, Assumption of Risk in Products Liability Cases, 22 LA. L. REv. 122 (1961).

${ }^{18}$ See the majority and dissenting opinions in Jamieson v. Woodward \& Lothrop, 247 F.2d 23 (D.C. Cir. 1957). See also Noel, Manufacturer's Negligence of Design or Directions for Use of a Product, 71 YATE L.J. 816, 836-37 (1962).

10 See, e.g., Cochran v. Brooke, 409 P.2d 904 (Ore. 1966). Cf. Kaempfe v. Lehn \& Fink Prod. Corp., 21 App. Div. 2d 197, 249 N.Y.S.2d 840 (1st Dept. 1964), motion to dismiss appeal detried, 16 N.Y.2d 1044, 266 N.Y.S.2d 118, 213 N.E.2d 451 (1965).

Self-protective care may also be rendered less effective if the use of the product is likely to become habit forming before the user has a chance to know whether he is one of the few whom it is likely to hurt. Cf. Traynor, The Ways and Meanings of Defective Products and Strict Liability, 32 TENN. L. Rev. 363, 371 (1965) ("Given the habit forming nature of cigarettes, it is questionable how voluntarily many consumers are continuing to smoke.").

20 RestateMrent (SeCOND), ToRTs § 402A comment k (1965).

21 Grau v. Procter \& Gamble Co., 324 F.2d 309 (5th Cir. 1963) (only one other known individual reaction besides plaintiff's); Merrill v. Beaute Vues Corp., 235 F.2d 893 
If the danger that lurks in the product is unknown and unknowable at the time it was put out, the question arises whether the maker should be held on a warranty or strict tort liability theory. The conceptual argument that he should be liable points out, first, that a product is unreasonably dangerous if the condition or quality would be so regarded by a reasonably prudent person who knew of it, and, second, that the very essence of the distinction between negligence and strict liability is that scienter is not required for the latter. ${ }^{22}$ Some cases proceed on the analogy of the undiscoverable defect-such as foreign substance in food in a sealed container-which is a typical basis for warranty liability. ${ }^{23}$ Mr. Connolly, in a thoughtful article, attacks the analogy, however, by pointing out that ordinary defects, while not discoverable in the specific instance, are nevertheless foreseeable in the broad sense that renders them a calculable cost of doing business. ${ }^{24}$ If strict hability is to be justified as a vehicle for spreading losses which are inseparable from the production of commodities, Connolly contends that this factor is important, for only calculable risks lend themselves to the principles of insurance and risk spreading. "[W] hen the risk itself is unknown, the seller is not in a position to spread it . . ."25 He concludes that such risks as these should be covered by the victim's own accident or health insurance, or by the state.

This is a plausible position but it overlooks considerations which point to an opposite conclusion. For one thing, as Professor Ehrenzweig has pointed out: "The average consumer cannot realistically be expected to carry the accident or health insurance he needs even under the products liability laws of his home state." ${ }^{26}$ As for state insurance against such risks, a good case can indeed be made for it, yet it has its disadvantages. ${ }^{2 \tau}$

(10th Cir. 1956) ; Hunter v. E. I. du Pont de Nemours \& Co., 170 F. Supp. 352 (W.D. Mo. 1958); Howard v. Avon Prods., Inc., 155 Colo. 444, 395 P.2d 1007 (1964). But cf. the analysis of Braun v. Roux Distrib. Co., 312 S.W.2d 758 (Mo. 1958) in Noel, The Duly to Warn Allergic Users of Products, 12 VAND. L. REv. 331 (1959).

See also Whitmore, Allergies and Other Reactions Due to Drugs and Cosmetics, 19 Sw. L.J. 76 (1965).

22 P. Keeton, Products Liability-Liability Without Fault and the Requirement of a Defect, 41 TExAs L. Rev. 855 (1963).

${ }^{23}$ See, e.g., Green v. American Tobacco Co., 154 So. 2d 169 (Fla. 1963).

24 Connolly, The Liability of a Mamufacturer for Unknowable Hazards Inherent in His Product, 32 Ins. Counser J. 303 (1965).

25 Id. at 307.

26 Ehrenzweig, Products Liability in the Conflict of Laws-Toward a Theory of Enterprise Liability Under "Foreseeable and Insurable Lawes," 69 YALE L.J. 794, 801 (1960).

27 For example, the approach of enterprise liability, in contrast to that of state insurance, would preserve more of the values of the free enterprise system. See also Calabresi, The Decision for Accidents: An Approach to Nonfault Allocation of Costs, 78 HARv. L. REv. 713, 744 (1965). 
It is not with us yet, and may never be, and the question remains what the courts should do in the meantime. But there may be a more fatal flaw in Mr. Connolly's reasoning than either of these. That the specific risk is unknown and unknowable in advance is not as significant as he seems to think, where the risk is of a type which is foreseeable. It may be, for example, that the cigarette industry was justifiably ignorant as late as the mid-fifties of the tendency of its product to cause cancer. But the creation of substantial health hazards by excessive use of cigarettes was a matter of common knowledge when my generation first became conscious of the joys of smoking, at the time of the First World War. Some specific side-effects of a new drug may be undiscoverable and unsuspected, but the risk of side-effects injurious to health is now well known.

Risks of this foreseeable type should be distinguished from those of an altogether different type. If, for example, a drug unsuspectedly made its user prone to commit forgery, the economic loss suffered by the victim of the forgery would indeed be beyond anything that the drug's maker could be expected to calculate and provide for. At least until such a consequence of the drug's use became known it could scarcely be regarded as typical of the inaker's enterprise. On the other hand, where hitherto unknown and unknowable risks, revealed by the occurrence of injury, fall within the broad type of hazard which foreseeably would be created by the enterprise, it is submitted that they should be considered in determining whether a product is unreasonably dangerous. That these risks are not more narrowly foreseeable does not mean that the maker camiot or should not provide for them and distribute them as costs typical of his enterprise. ${ }^{28}$

If the view here proposed is accepted, it will not mean automatic liability for all mjuries caused by unknown dangers of a product. Rather it will call upon the courts to make the same kind of judgnient that they have to make about the known liazards of products-whether they render the product unreasonably dangerous. Of course if the danger was unknowable, that fact will itself enter into the making of that judgnient. For one thing, the danger may have been greater because the chance for selfprotective care afforded by knowledge of the danger could not be relied on to reduce it. Moreover, courts will not liave the benefit (whatever it is worth) of the implied political judgment that may be inferred from popular acquiescence in a widely known danger. But these things would not make the task of judgment unmanageable.

It has been suggested that a court "seems poorly equipped to balance

${ }^{28}$ See Morris, Enterprise Liability and the Actuarial Process-The Insignificance of Foresight, 70 YaIE L.J. 554 (1961). 
the utility of a product against the risk," and that judgments like these should be made by administrative boards with their staffs of experts. ${ }^{20}$ But this approach fails to recognize that courts are constantly called upon to make just this sort of judgment througlout the whole field of products liability, and indeed the whole field of negligence. Surely there is no good reason why they should cease to exercise this function in the area where the specific danger was formerly unknown. If anything, the need for judicial judgment seems greater here since, by hypothesis, the administrative experts (or the legislature) had no information to act upon at the time of the events which led to the action before the court.

\section{III}

\section{A FURTHER INQUIRY}

Up to this point, the prevailing requirement of unreasonable danger in the product has been accepted without question. This means that risk is balanced against utility under any current theory of hability. This in turn means that the hapless victim of an "unavoidably unsafe" but useful product cannot recover ${ }^{30}$ That is the fate today of one who has an unsuspected idiosyncratic sensitivity to a useful drug, ${ }^{81}$ or of the unlucky individual who happens to receive hepatitis virus in whole blood..$^{32}$ One may well ask wiy. To be sure, the utility of drugs and blood transfusions is so great that the social interest demands they be permitted even though they take a small but unfortunate toll. But is not this the typical setting for strict hability? The single victim's phight is just as bad as that of a member of a larger group of allergic persons whose common sensitivity to another product has led the court to judge its condition unreasonably dangerous. The single victim's need for compensation is just as great. His chance to protect himself may have been even smaller. Under a scheme of broad social insurance against health hazards it would be arbitrary if not monstrous to exclude his case. If he is not to recover under enterprise liability, it must be because this loss is not properly regarded as a cost of the enterprise - as "typical" of it. This may be a questionable judgment, but I see no signs that the courts are likely to depart from it. ${ }^{38}$

28 Connolly, supra note 24 , at 306 .

30 RESTATEMENT (SECOND), TORTS \& 402A comment $k$ (1965).

31 Cochran v. Brooke, 409 P.2d 904 (Ore. 1966).

$32 \mathrm{On}$ one basis or another, recovery has been consistently denied in these cases. Fischer v. Wilmington Gen. Hosp., 51 Del. 554, 149 A.2d 749 (1959); Balkowitsch v. Minneapolis War Memorial Blood Bank, 270 Minn. 151, 132 N.W.2d 805 (1965); Perlmutter v. Beth David Hosp., 308 N.Y. 100, 123 N.E.2d 792 (1954); P. Keeton, Products LiabilityLiability Without Fault and the Requirement of a Defect, 41 TExAS L. REv. 855, 860-61 (1963); Traynor, supra note 19, at 367-68.

33 The question has however been raised by Chief Justice Traynor of the Supreme Court of California. Traynor, supra note 19. 